\title{
Research on Risk Evaluation Index System of Intellectual Property Pledge Financing in Large Data Enterprises
}

\author{
Mu Zhang ${ }^{1, a,{ }^{*}}$, Xiao-nan Huang ${ }^{1,2,3, b}$ \\ ${ }^{1}$ School of Finance, Guizhou University of Finance and Economics, Guiyang Guizhou 550025, China; \\ ${ }^{2}$ Guizhou Institution for Technology Innovation \& Entrepreneurship Investment, Guizhou University of \\ Finance and Economics, Guiyang Guizhou 550025, China; \\ ${ }^{3}$ Guizhou Institute for Urban Economics and Development, Guizhou University of Finance and Economics, \\ Guiyang Guizhou 550025, China. \\ arim_007@163.com, b15800726830@163.com \\ * Corresponding author
}

Keywords: Large data enterprises; Intellectual property; Intellectual property pledge financing; Risk of intellectual property pledge financing; Index system.

\begin{abstract}
The purpose of this paper is to improve the level of risk analysis and management in intellectual property pledge financing mode, so as to promote further credit support to the large data enterprises. According to the connotation and business process of intellectual property pledge financing, this paper analyzed the main risk sources in intellectual property pledge financing. On this basis, combining with the basic elements of credit assessment of large data enterprises, and following the selection principles of evaluation index, this paper constructed a credit risk evaluation index system for the large data enterprises in intellectual property pledge financing mode, from the following aspects: business risk, intellectual property risk, pledge management and liquidity risk, etc. This index system gives prominence to the characteristics of large data enterprises, such as the technological innovation capacity, and covers the main risk sources in intellectual property pledge financing. So it lays the foundation for follow-up evaluation.
\end{abstract}

\section{Introduction}

Large data industry belongs to intellectual property intensive industry. Carrying out intellectual property pledge financing business will help broaden the financing channels of large data enterprises and increase credit support for large data enterprises. However, the imperfect laws and regulations related to intellectual property rights, the immature market of intellectual property transactions, the difficulty in assessing the value of intellectual property rights, and the difficulty in measuring and controlling the risks of intellectual property pledge financing have hindered the healthy development of intellectual property pledge financing in China, especially the risks in the process of intellectual property pledge financing. The most widespread and difficult to measure problem is the most serious. Therefore, the establishment of a reasonable and effective intellectual property pledge financing risk evaluation index system is particularly important.

Research at home and abroad shows that intellectual property pledge financing business in operation faces many risks, such as operating risk [1-3], infringement risk [4], valuation risk [5], disposal risk [6], legal risk [7]. For example, Qi Panpan, Yang Xiaoye and Niu Nuonan (2012) [8] believe that intellectual property pledge financing risk factors mainly include legal factors, intellectual property factors, enterprise factors, banking factors, macro factors and other five aspects. Zhang Jieqian (2013) [2] defines the evaluation index of intellectual property financing risk of science and technology SMEs as three first-level indicators: intellectual property risk, pledge management and Realization risk, and operation risk of science and technology SMEs. He Huifang and Liu Changhong (2013) [9] hold that the internal risk refers to the risks existing in the production and operation of the enterprises before the financing of intellectual property pledge, such as technology risk, production risk, market risk, management risk, etc. The External risk refers to risks caused by external uncertainties after intellectual property pledge 
financing, such as financial risks, policy and legal risks, regional social risks and so on. Deng Wenbin, Li Honghan and Zhou Kai (2015) [10] put forward the risk coefficient evaluation index of intellectual property pledge loan, including legal risk, macro-environmental risk, intellectual property risk itself, intellectual property evaluation risk. Yin Xianan, Bao Xinzhong and Zhu Lianmei (2016) [11] construct a complete set of quantitative index evaluation system of intellectual property pledge financing enterprise risk from four latitudes: financial control risk, management control risk, intellectual property risk and government behavior related risk. Zeng Li and Wang Ming (2016) [12] set up an evaluation index system for intellectual property pledge financing risk of small and medium-sized scientific and technological enterprises, which includes 10 first-class indicators such as evaluation risk, market risk, production risk, acceptance risk, technology risk, legal risk, policy risk, financial risk, management risk, regional risk, etc. Bao Xinzhong and Dong Yuhuan (2016) [13] use five first-class indicators to evaluate the risk of intellectual property pledge financing, such as legal risk, intellectual property risk, business risk of the lending enterprise, bank risk, macro-risk and so on.

To sum up, there are abundant research results on risk analysis and management of intellectual property pledge financing in China. However, most of the existing literatures focus on small and medium-sized enterprises in science and technology, and lack of research results on large data enterprises. In view of this, according to the connotation and business process of intellectual property pledge financing, this paper analyzes the main risk sources of intellectual property pledge financing for large data enterprises. On this basis, combined with the characteristics of large data enterprises, following the selection principle of evaluation indicators, the paper constructs the risk evaluation index system of intellectual property pledge financing for large data enterprises.

\section{Major Risk Sources of Intellectual Property Pledge Financing for Large Data Enterprises}

According to the Notice on Enhancing the Management of Intellectual Property Pledge Financing and Assessment to Support the Development of Small and Medium-sized Enterprises, intellectual property pledge financing is a kind of financing way that intellectual property rights holders pledge their lawful and still valid intellectual property rights, such as patent rights, registered trademark rights, copyrights and so on, obtain funds from banks and other financial institutions, and repay capital principal and interest on time. According to the relevant provisions of the property law of the People's Republic of China, there are three main types of intellectual property pledge financing in China: patent pledge financing, trademark pledge financing and copyright pledge financing.

At present, the business process of intellectual property pledge financing in China mainly includes the following steps: (1) Enterprises submit written applications for intellectual property pledge loans to banks; (2) The value of intellectual property pledged by enterprises is assessed by professional appraisal institutions; (3) Banks review the evaluation results submitted by enterprises; (4) After the bank has passed the examination and approval, the two parties signed the loan contract and the pledge contract; (5) The two parties hold relevant documents to the intellectual property management department for registration of pledge right; (6) Execute loan contract.

According to the connotation and business process of intellectual property pledge financing, the main risk sources of intellectual property pledge financing for large data enterprises include:

(1) Business risk. Operational risk is the primary risk of intellectual property pledge financing. It refers to the possibility of negative impacts caused by various uncertainties in the process of production and operation. For large data enterprises, business risks can be considered from both internal and external risks. Internal risks mainly include financial risks (such as solvency, operating capacity, profitability, etc.), production risks (such as data processing capacity, technical equipment and technology, etc.). External risks mainly include macroeconomic conditions (such as national policies, market interest rates, etc.), industry development (such as industry development trends, industry competitiveness, etc.).

(2) Intellectual property risks. Intellectual property risk refers to the patent, trademark, marketing program and confidentiality in research and development, production, operation, sales and use of 
infringement, occupation, causing contradictions and so on. It mainly includes intellectual property management level, intellectual property rights and intellectual property protection [2]. The level of intellectual property management indicates the protection and operation ability of the enterprise to the relevant intellectual property rights. Ownership of intellectual property rights refers to which party the ownership of intellectual property rights belongs to, the possibility of determining whether the property rights belong to the assets of the enterprise and the possibility of subsequent ownership disputes [14]. Intellectual property protection risk refers to the risk caused by the validity period and technical content of intellectual property when protecting intellectual property.

(3) Pledge management and liquidity risk. Pledge management accompanies the whole process of intellectual property pledge financing, and the realization of pledge is the last guarantee for banks and other financial institutions as the pledge. Professional appraisal institutions in the valuation of intellectual property rights, due to a variety of factors caused by the value of difficult to accurately assess, thus resulting in valuation risk. Guarantee arrangements such as pledge rate and ransom period are the key sources of contract design risk in intellectual property pledge financing [15]. The pledge rate, that is, the ratio of the loan amount to the value of the pledged intellectual property rights, can reflect the risk situation of intellectual property pledge financing more comprehensively. Redemption refers to the process in which the borrowing enterprise withdraws or dissolves the corresponding value pledge by means of supplementary margin (or cash equivalent) and repayment of loans to offset the credit exposure during the ransom period. The liquidation risk of pledge is the most important risk in the financing of intellectual property pledge, which mainly includes the price risk of intellectual property, transfer risk and so on.

\section{Index System Construction}

According to the connotation of intellectual property pledge financing and the main risks it faces, based on the previous studies and combined with the characteristics of large data enterprises (such as technological innovation capability, industry growth, etc.), following the selection principles of scientific, objective, systematic, functional, dynamic, relatively independent, feasible (or operational) and comparable evaluation indicators, this paper constructs the risk evaluation index system of intellectual property pledge financing for large data enterprises from three aspects: business risk, intellectual property risk, pledge management and liquidation risk, as shown in Table 1.

Table 1 Risk assessment index system of intellectual property pledge financing for large data enterprises

\begin{tabular}{|c|c|c|}
\hline First level index & Second level index & Third level index \\
\hline \multirow{6}{*}{$\begin{array}{c}\text { Business risk } \\
U_{1}\end{array}$} & Solvency $U_{11}$ & Current ratio $U_{111}$; Quick ratio $U_{112}$; Asset-liability ratio $U_{113}$ \\
\hline & $\begin{array}{l}\text { Operating capacity } \\
\qquad U_{12}\end{array}$ & $\begin{array}{c}\text { Receivable turnover } U_{121} \text {; Total asset turnover } U_{122} ; \\
\text { Inventory turnover } U_{123}\end{array}$ \\
\hline & Profitability $U_{13}$ & OPE $U_{131} ; \operatorname{ROE} U_{132} ;$ Total assets yield $U_{133}$ \\
\hline & Growth ability $U_{14}$ & $\begin{array}{l}\text { Net profit growth rate } U_{141} \text {; Growth rate of main business } \\
\qquad U_{142}\end{array}$ \\
\hline & $\begin{array}{c}\text { Technological } \\
\text { innovation capability } \\
U_{15} \\
\end{array}$ & $\begin{array}{c}\text { Development expenditure } U_{151} \text {; Growth rate of intangible } \\
\text { assets } U_{152} \text {; Number of invention patent applications } \\
\text { published } U_{153}\end{array}$ \\
\hline & Industry growth $U_{16}$ & Industry average operating income growth rate $U_{161}$ \\
\hline \multirow{3}{*}{$\begin{array}{l}\text { Intellectual } \\
\text { property risks } \\
U_{2}\end{array}$} & $\begin{array}{l}\text { Intellectual property } \\
\text { management level } U_{21}\end{array}$ & $\begin{array}{c}\text { Intellectual property risk prevention awareness } U_{211} \text {; } \\
\text { Standardization of intellectual property legal affairs } \\
\text { management } U_{212}\end{array}$ \\
\hline & $\begin{array}{l}\text { Intellectual property } \\
\text { rights } U_{22}\end{array}$ & $\begin{array}{c}\text { Whether the ownership clear } U_{221} \text {; Whether there are } \\
\text { duplicate guarantee } U_{222}\end{array}$ \\
\hline & $\begin{array}{l}\text { Intellectual property } \\
\text { protection } U_{23}\end{array}$ & $\begin{array}{c}\text { Validity and geographical restrictions } U_{231} \text {; Intellectual } \\
\text { property technology content } U_{232} \text {; Intellectual property } \\
\text { infringement possibility } U_{233}\end{array}$ \\
\hline
\end{tabular}




\begin{tabular}{|c|c|c|}
\hline \multicolumn{3}{|r|}{ Cont. to Table 1} \\
\hline \multirow{3}{*}{$\begin{array}{c}\text { Pledge } \\
\text { management } \\
\text { and liquidity } \\
\text { risk } U_{3}\end{array}$} & $\begin{array}{l}\text { Intellectual property } \\
\text { valuation risk } U_{31}\end{array}$ & $\begin{array}{l}\text { Qualification and reputation of evaluation institutions } U_{311} \text {; } \\
\text { Scientific rationality of evaluation methods } U_{312}\end{array}$ \\
\hline & $\begin{array}{c}\text { Guarantee } \\
\text { arrangement } U_{32}\end{array}$ & pledge rate $U_{321}$ \\
\hline & $\begin{array}{l}\text { Intellectual property } \\
\text { liquidation risk } U_{33}\end{array}$ & $\begin{array}{l}\text { The stability of intellectual property value } U_{331} \text {; } \\
\text { Transferability of intellectual property } U_{332} \text {; The degree of } \\
\text { perfection of intellectual property market } U_{333}\end{array}$ \\
\hline
\end{tabular}

Part three level indicator description:

\subsection{Business risk.}

Development expenditure is the part of expenditure that reflects the cost of intangible assets that can be capitalized in the process of developing intangible assets. The growth rate of intangible assets refers to the ratio of intangible assets at the end of the assessment period to the end of the previous period. It reflects the growth rate of intangible assets and is a relative index. The growth rate of the average business income of an industry refers to the ratio of the increase of the business income of a certain industry in this year to the total business income of the previous year.

\subsection{Intellectual property risks.}

Intellectual Property Risk Awareness (IPR) indicates whether the enterprise leaders can foresee the possible risks and take relevant actions to reduce the occurrence of risks. Strong awareness of IPR risk prevention can effectively reduce unnecessary risks. A duplicate guarantee means that the same pledge is guaranteed to multiple creditors. The term of validity and geographical limitations refer to that in the process of intellectual property protection, the relevant documents define the term of validity and geographical scope of intellectual property protection, emphasizing the scope of protection. Technological content refers to the increment of added value of products due to technological factors. The technological content of intellectual property rights should include the innovation of knowledge, the advancement of product technology and the high-end of scientific equipment. The possibility of infringement of intellectual property rights is represented by the probability of copying or copying in the process of using intellectual property rights.

\subsection{Pledge management and liquidity risk.}

The qualification and reputation of an appraisal institution refers to the credit and reputation recognized by the public in the appraisal activities when the appraisal institution has the conditions to carry out the appraisal activities. The stability of the value of intellectual property is an important index to measure whether the value of intellectual property fluctuates at a certain stage, which is determined by the development of science and technology, macroeconomic situation and business environment, and affects the realization of intellectual property. The transferability of intellectual property refers to the legal act of transferring intellectual property rights from the transferor to the transferee by signing an intellectual property transfer contract between the transferor and the transferee in accordance with relevant laws and regulations. The perfection of the intellectual property trading market is an index to measure the development of the intellectual property trading market. It reflects the effectiveness and accuracy of the operation of the trading market.

\section{Summary}

In this paper, aiming at the problem that the risk sources are wide and difficult to measure in the process of intellectual property pledge financing, according to the connotation and business process of intellectual property pledge financing, the main risk sources of intellectual property pledge financing in big data enterprises are analyzed, and from the aspects of enterprise operation risk, intellectual property risk, pledge management and realization. In three aspects, the risk evaluation index system of intellectual property pledge financing for large data enterprises, including 12 secondary indicators and 28 tertiary indicators, is constructed. The specific meaning of the third level index is explained in detail. The index system highlights the characteristics of large data enterprises such as technological innovation ability and 
industry growth, and covers the main risk sources of intellectual property pledge financing, thus laying a foundation for the follow-up evaluation.

\section{Acknowledgment}

This work was financially supported by National Natural Science Foundation of China (71861003).

\section{References}

[1]. Zhang Boyou, "Risk decomposition and step-by-step control of intellectual property pledge financing,” Intellectual Property, vol.19, No.2, pp. 30-34, Mar 2009.

[2]. Zhang Jieqian, "Risk Management on Intellectual Property Pledge Financing by Small and Medium S\&T Enterprises-from the Aspect of Bank," Scientific Management Research, vol.31, No.2, pp. 98-101, April 2013.

[3]. Li Haiyin, Yuan Zeming, and Li Shuanghai, "Risk assessment of innovative enterprise's intellectual property pledge loan,” Studies in Science of Science, vol.35, No.8, pp. 1253-1263, August 2017.

[4]. Crawford J, Strasser R, "Management of Infringement Risk of Intellectual Property Assets," Intellectual Property \& Technology Law Journal, vol. 20, No.20, pp. 7-10, 2008.

[5]. Bao X Z et al, "Risk Evaluation of Value Assessment in IPR Pledge Financing Based on Interval Value TOPSIS Method,” in Proceeding of 2015 International Conference on Logistics, Informatics and Service Sciences (LISS). Barcelona, Spain: IEEE, 2015, pp. 1-7.

[6]. Eggleston, Barbieri, and Carmen R, “IP Collateral: An Emerging Financing Tool,” Managing Intellectual Property, No.92, pp. 83-87, April 1999.

[7]. Davies I, "Secured Financing of Intellectual Property Assets and the Reform of English Personal Property Security Law,” Oxford Journal of Legal Studies, vol.26, No.3, pp. 559-583, 2006.

[8]. Qi Panpan, Yang Xiaoye, and Niu Nuonan, "Research on risk assessment model of intellectual property pledge financing,” Friends of Accounting, No.9, pp. 102-105, 2012.

[9]. He Huifang, Liu Changhong, “The Evaluation Research of the Intellectual Property Rights Pledge Risk Pre-warning Based on the Fuzzy Comprehensive Analysis,” Science and Technology Management Research, No.14, pp. 151-159, 2013.

[10]. Deng Wenbin, Li Honghan, and Zhou Kai, "Risk assessment of intellectual property pledge loan in commercial banks-An Empirical Study Based on A Publishing Enterprises,” South China Finance, No.05, pp. 77-83, 2015.

[11]. Yi Xianan, Bao Xinzhong, and Zhu Lianmei, "Study on Risk Evaluation of Intellectual Property Pledge Financing from the View of Financing Enterprises," Science and Technology Management Research, No.12, pp. 125-129, 2016.

[12]. Zeng Li, Wang Ming, “Risk Assessment of Intellectual Property Pledge Financing of Small and Medium Sized Enterprises Based on BP Neural Network," Science and Technology Management Research, No.23, pp. 164-167, 2016.

[13]. Bao Xinzhong, Dong Yuhuan, "Risk assessment of intellectual property pledge financing-Based on bank Perspective,” Journal of Nanjing Audit University, No.2, pp. 48-56, 2016.

[14]. Chen Jianli, "Risk control of intellectual property pledge financing for small and medium sized technological enterprises,” Economic Review, No.7, pp. 113-116, 2011.

[15]. Y. X. Li, Risk Control of Contract Design of Inventory Financing under Logistics Financial Innovation, East China Economic Management, vol. 26, No.7, pp. 141-144, 2012. 